Vol. 20 (2011): 74-85.

\title{
Introduced pathogens found on ornamentals, strawberry and trees in Finland over the past 20 years
}

\author{
Arja Lilja ${ }^{1^{*}}$, Anna Rytkönen ${ }^{1}$, Jarkko Hantula ${ }^{1}$, Michael Müller ${ }^{1}$, Päivi Parikka ${ }^{2}$ and Timo Kurkela ${ }^{1}$ \\ ${ }^{1}$ Finnish Forest Research Institute, South-Finland unit, P.O. Box 18 FI-01301 Vantaa \\ ${ }^{2}$ MTT, Agrifood Research Finland, FI-31600 Jokioinen \\ *e-mail:arja.lilja@metla.fi
}

The comparative ease and speed of international trade and travel have enabled or enhanced the spread of pests around the globe. For example, trade in ornamental plants has bolstered the spread of alien Oomycetes such as pathogenic species of Phytophthora. To date, four Phytophthora species have been identified in Finland: P. cactorum on Fragaria $\mathrm{x}$ ananassa, Betula pendula and Rhododendron spp., P. plurivora on Rhododendron spp. and Syringa vulgaris, and P. pini and P. ramorum on Rhododendron spp. The ascomycete Colletotrichum acutatum, which was listed as a quarantine pathogen by the European Union until 2009, was introduced in 2000 and can survive in plant debris over two winters in Finland. Positive PCR results have also been obtained from bait plants grown in soil collected from locations where diseased Fragaria $\mathrm{x}$ ananassa plants had earlier been destroyed. In the mid-1990s, there was an epidemic of foliar rust caused by the Asian basidiomycete Melampsoridium hiratsukanum on Alnus glutinosa and A. incana. Recently, two ascomycetes that have been introduced are Dothistroma septosporum (responsible for red band needle blight on Pinus sylvestris) and Chalara fraxinea (causing ash decline on Fraxinus excelsior).

Key-words: Phytophthora, Colletotrichum acutatum, Melampsoridium hiratsukanum, Dothistroma septosporum, Chalara fraxinea, plant pathology, climate change. 
Vol. 20(2011): 74-85.

\section{Introduction}

Alien species are introduced by man, most often accidentally, and are more or less naturalized in areas outside their natural range and typically exhibit low genetic variation (Sakai et al. 2001). All non-natives compete with indigenous species and some may be harmful plant pathogens. The comparative ease and speed of international trade and travel have enabled pests to disperse around the globe more effectively than their biology would otherwise allow. In addition to human-mediated transport, many fungi produce spores that permit their spread over great distances.

A classical example of an alien species is Phytophthora infestans (Mont.) de Bary, the pathogen responsible for potato late blight. This fungus was introduced into Europe from South America on potato tubers where it caused the Great Irish Potato Famine of 1845-1850. Even today, P. infestans limits potato production throughout the world (Erwin and Ribero 1996). The ornamental plant trade in particular has unwittingly spread Phytophthora and the ecological consequences have in some cases been significant. For example, P. cinnamomi Rands is an omnivorous pathogen infecting many plant species used in agriculture and forestry (Erwin and Ribeiro 1986). Since its introduction, $P$. lateralis Tucker \& Milbrath (the cause of Port Orford Cedar Root Disease) has threatened Lawson's cypress (Chaemaecyparis lawsoniana (A. Murr.) Parl.), an important native tree species in riparian areas of Oregon and California (Zobel et al. 1985, Hansen et al. 2000, Hansen 2008).

Information on the biology and impact of introduced species are fundamental components of successful management programs targeting non-native pathogens. The aim of this article is to compile information on introduced pathogens, airborne fungi and alien Phytophthora that have been isolated from ornamentals, strawberry plants and trees in Finland. Each section summarizes the research on a particular pathogen, its pathology and likely means of introduction.

\section{Phytophthora cactorum, an established new pathogen}

Phytophthora cactorum (Leb. and Cohn) Schröter occurs worldwide and causes root and collar rots, fruit rots, cankers, leaf blights and wilts in over 200 plant species (Erwin and Ribeiro 1996). In Finland, P. cactorum was isolated for the first time in 1990 from strawberry (Fragaria $\mathrm{x}$ ananassa Duch.) plants presenting symptoms of crown rot (Parikka 1990). A year later, it was found in necrotic stem lesions of silver birch (Betula pendula Roth) (Lilja et al. 1996). Typically, necrosis in the crown causes wilt and dieback of strawberry plants. In birch, necrotic lesions occur on stems and leaves but roots are unaffected. The pathogen can survive in soil or organic matter for a considerable period of time, even when winter temperatures drop below $0{ }^{\circ} \mathrm{C}$ (Grove et al. 1985, Lilja et al. 2006). Today P. cactorum is an important pathogen in agriculture and forestry (Juntunen 2000, Lilja et al. 2006).

According to our observations, Finnish isolates of $P$. cactorum from strawberry and birch are morphologically distinguishable in terms of the relative size of oogonia, oospores and sporangia (Hantula et al. 2000). Although individual variation in morphology is evident, microscopic examinations could not identify intraspecific genetic groups or establish host specificity among isolates from apple, birch, rhododendron and strawberry (Stamps et al. 1990, Hantula et al. 2000). However, both random amplified microsatellite (RAMS) and random amplified polymorphic DNA (RAPD) fingerprinting analyses revealed substantial genetic variation among isolates of $P$. cactorum, and isolates from birch and European strawberry formed separate groups in cluster analyses (Hantula et al. 1997, 2000, Lilja et al. 1998).

A subsequent analysis of amplified fragment length polymorphisms (AFLP) revealed that 16 of 23 crown rot isolates from Europe, Japan, Australia and New Zealand were identical (Eikemo et al. 2004). However, isolates from strawberry plants in different states or from different host plants in Germany, Canada and the US were polymorphic 
Lilja, A. et al. Introduced pathogens found on ornamentals, strawberry and trees

and formed 42 unique AFLP profiles (Huang et al. 2004). We also found high genetic variation within the North American population of $P$. cactorum infecting strawberry (Hantula et al. 2000). The high variation suggests that $P$. cactorum originates in North America and instances of the pathogen in Europe, Oceania, Asia and Africa are transplants of that population (Hantula et al. 2000, Eikemo et al. 2004, Huang et al. 2004). Crown rot isolates in Europe are genetically identical (Hantula et al. 1997, 2000, Lilja et al. 1998, Eikemo et al. 2004), perhaps representing a single clonal genotype that may reflect the extensive migrations of isolates via propagation material transported throughout $\mathrm{Eu}-$ rope. The spread of $P$. cactorum in birch remains to be determined since genetic analysis has only been completed for isolates from Finland (Hantula et al. 1997, 2000, Lilja et al. 1998, Eikemo et al. 2004).

\section{Phytophthora ramorum, a new invader causing severe problems elsewhere}

A new species of Phytophthora, P. ramorum Werres de Cock \& Man in't Veld, was described by Werres et al. (2001) and shown to be associated with twig blight on rhododendron (Rhododendron spp.) and viburnum (Viburnum spp.) in Germany and the Netherlands. Later, the same fungus was found to be responsible for the death of oaks (Quercus spp.) and tanoaks [(Lithocarpus densiflorus (Hook \& Arn.) Rehd.] in native forest ecosystems of coastal California and southwestern Oregon (Rizzo et al. 2002, 2005, Davidson et al. 2005, Prospero et al. 2009). The disease is known as sudden oak death (SOD).

In the spring of 2004, P. ramorum was found for the first time in Finland. It was isolated following a positive PCR-test from commercial rhododendron plants imported from other EU member states (Lilja et al. 2007). The pathogen was subsequently identified the following August in Rhododendron catawbiense Michx and several other cultivars produced by micropropagation in a Finnish nursery (Lilja et al. 2007). Since then, the Finnish Food Safety Authority (Evira) has carried out extensive surveys at the nursery. Today, we know that the pathogen remains in the nursery although all rhododendron seedlings and growth media have been destroyed every year in the area where the disease has been found. Routine examinations rely on a $P$. ramorum-specific PCR. The verification of morphological identification of isolates was done by partial $\beta$-tubulin gene sequencing (Lilja et al. 2007).

Risk analyses assume that the success of a pest introduction is positively correlated with the extent of its host range (Cave et al. 2005). P. ramorum has many hosts in different plant families (Hansen et al. 2005, Denman et al. 2005). In our pathogenicity tests, $P$. ramorum caused stem lesions on silver birch and even more serious symptoms on rhododendron, viburnum (Viburnum lentago L.), bug bilberry (Vaccinium uligonosum L.) and blueberry ( $V$. myrtillus L.), but strawberry, English oak (Quercus robur L.), Scots pine (Pinus sylvestris L.) and Norway spruce (Picea abies (L.) Karst.) were resistant (Lilja et al. 2007, 2010). Although the pathogen has been detected in many European hardwoods (Brasier et al. 2004, EPPO 2010), a serious SOD epidemic has so far only occurred in the western US. In Europe, P. ramorum has mainly been implicated as the cause of leaf, twig and shoot blight in different ornamental hosts found commonly in nurseries and parks and infected trees have grown near diseased rhododendrons (Werres et al. 2001, EPPO 2010). However, in August - October 2009 widespread dieback and mortality of both mature and young Japanese larch [Larix kaempferi (Lanb.) Carriere] was reported from multiple sites in southwest England, and no infected rhododendrons were found in the vicinity of the diseased trees (EPPO 2010).

It is not known how P. ramorum originally entered Europe or North America, but the mating type, morphology, growth characters, and population distribution with three distinct clone lineages suggest that separate introductions may have occurred from a third and presently unknown location (Brasier 2003, Rizzo et al. 2005, Werres and Kaminski 2005, Goss et al. 2009, Prospero et al. 2009). The main source of the pathogen is most likely the importation of infected ornamentals. 
Vol. 20(2011): 74-85.

\section{Phytophthora plurivora and P. pini, two taxonomically-related invaders in nurser- ies}

The P. citricola species complex is found worldwide on numerous host species (Erwin and Ribeiro 1996). Previous attempts to unravel the taxonomy of this complex include isozyme analysis and single-strandconformation polymorphism of ribosomal DNA (SSCP) fingerprinting techniques (Oudemans et al. 1994, Kong et al. 2003). Both genetic analyses revealed several distinct subgroups, although in most cases no differences in morphology or host range were detected (Oudemans et al. 1994, Kong et al 2003). Two molecular phylogenetic studies of the internal transcribed regions (ITS1 and ITS2) and 5.8S gene of the rRNA operon, the mitochondrial cox 1 and $\beta$-tubulin genes revealed two new species in the P. citricola complex (Scott et al. 2009, Jung and Burgess 2009). Moreover, these studies divided the species complex into five groups:1) P. citricola s. str. 2) P. citricola, subgroup I, 3) P. plurivora T. Jung \& T.I. Burgess, 4) P. citricola subgroup III, and 5) P. multivora P.M. Scott \& T. Jung. Later the P. citricola I has proved to be P. pini L.H. Leonian, a species recently resurrected (Hong 2009). $P$. multivora is widespread in natural ecosystems of Western Australia, whereas P. plurivora is abundant in semi-natural ecosystems and nurseries across Europe where it causes bark necrosis, fine root loss and dieback in numerous species (Jung and Blaschke 1996, Nechwatal and Oßwald 2001, Jung et al. 2005, Jung and Nechwatal 2008, Scott et al. 2009). Many isolates representing these new species have in previous studies been called $P$. citricola or occasionally P. inflata N.E. Caroselli \& C.M. Tucker (Jung and Burgess 2009).

We have isolated $P$. plurivora [previously identified as $P$. inflata; based on the similarity of $\beta$-tubulin gene sequence to a reference strain in GenBank from rhododendron and common lilac seedlings (Syringa vulgaris L.) (Lilja et al. 2007)] and $P$.pini (previously identified as $P$. citricola $\mathrm{I}$ based on the similarity of $\beta$-tubulin gene sequence to a reference strain in GenBank), from rhododendron cultivars in Finland. Members of $P$. pini are widespread in the eastern US and cause damage and mortality in introduced species such as European beech (Fagus sylvatica L.) (Jung et al. 2005). In Europe, this species has only been found in nurseries, which indicates a recent introduction, possibly from the US. In our pathogenicity trials, both species infected most host plants including strawberry, rhododendron, silver birch, Norway spruce, bug billberry, blueberry, lingonberry (Vaccinium vitis-idaea L.) and common lilac. In our trials, the only resistant woody species was Scots pine (Lilja et al. 2007).

\section{Colletotrichum acutatum, a new threat to agriculture}

Colletotrichum acutatum Simmonds is an omnivorous pathogen causing serious diseases on many agriculturally-important hosts such as almond [Prunus dulcis (Mill.) D.A. Web.], avocado (Persea spp.), peach (Prunus persica L.), apple (Malus domestica Borkh.), blueberries (Vaccinium spp.), citrus (Citrus spp.) and strawberry (EPPO 1997). The pathogen affects roots, leaves, blossoms, twigs, and fruits, and causes crown and root rot, defoliation, blossom blight, anthracnose and fruit rot.

Although C. acutatum has a very wide host range, it is economically most important in strawberries where it causes black-spot disease on fruits and petioles. Under suitable conditions sunken spots cover the entire fruit within a few days and salmon-pink spore masses are rapidly produced on infected tissues. The fungus can also live on plants as epiphytic and endophytic infections without visible symptoms (Freeman et al. 2001, Leandro et al. 2001). Anthracnose of strawberry was detected for the first time in Finland in August 2000. Symptoms became visible during warm and rainy weather on imported plant material maintained outdoors in the eastern part of the country (Parikka and Kokkola 2001, Parikka and Lemmetty 2004).

According to the literature, temperature and soil moisture strongly influence the survival of $C$. acutatum. The fungus survives best under cool, dry conditions where the growth and activity of 
Lilja, A. et al. Introduced pathogens found on ornamentals, strawberry and trees

competing microflora are depressed (Eastburn and Gubler 1990, 1992, Norman and Strandberg 1997). It can also infect several weed species and survive in their living tissues and debris (Berrie and Burgess 2003, Parikka and Lemmetty, 2009). In Norway, C. acutatum has also been detected in sour cherry (Prunus cerasus L.), two Cotoneaster-species, blackberry (Rubus fruticosus L.), raspberry (R. idaeus L.), nettle (Urtica dioica L.) and northern dock (Rumex longifolius D.C.) around infested strawberry fields (Stensvand et al. 2006). Survival of conidia and sclerotia in infected leaf debris declined rapidly under moist conditions $(>12 \%$ moisture, vol/wt), but under dry conditions conidia remained viable for up to 12 months when infested leaf debris was buried in soil (Norman and Strandberg 1997). Furthermore, Wilson et al. (1992) states that the fungus can overwinter in diseased berry residues under cool conditions. In our experiments, $C$. acutatum survived in plant debris on the soil surface for two winters (Lilja et al. 2006, Parikka et al. 2006). In infected weed debris, C. acutatum survived a summer exposed on the soil surface (Parikka and Lemmetty 2009). Conidia applied to denim fabric were recovered up to five weeks after application, indicating that contaminated clothing could transport conidia effectively within and between plants (Norman and Strandberg 1997). Splash dispersal has also been shown to be important in the local spread of the pathogen. The incidence of strawberry anthracnose $30 \mathrm{~cm}$ from an inoculum source increased from $25 \%$ after $30 \mathrm{sec}$ of rain to $99 \%$ after $16 \mathrm{~min}$. (Madden et al. 1992). Once the disease is introduced into a field, the pathogen spreads effectively by conidia and subsequent disease losses can be extensive. In our tests, more positive PCR results were obtained from bait plants grown in soil collected from the field where infected plants had been destroyed two years earlier than from samples collected a year after plant destruction (Lilja et al. 2006). Thus, strict hygiene and control in nurseries is needed to prevent the spread of the disease, since fungicides are not effective against $C$. acutatum.

\section{Melampsoridium hiratsukanum, an epi- demic caused by a recent range exten- tion of an alternate host}

Three fungi cause foliar rust on alders (Alnus spp.): Melampsoridium alni (Thümen) Dietel, $M$. betulinum (Fr.) Kleb. (Roll-Hansen and Roll-Hansen 1981), and M. hiratsukanum (Gäumann 1959, Wilson and Henderson 1966). During the 1970s, an epidemic in European alder was caused by $M$. betulinum, a species more commonly found on birch (Betula spp.) (Roll-Hansen and Roll-Hansen 1981). In the mid-1990s, a second epidemic of foliar rust took place in alders [Alnus glutinosa (L.) Gaertner and A. incana (L.) Moench] in Estonia and Finland (Põldmaa 1997, Kurkela et al. 1999). The morphological similarity of the pathogen to M. hiratsukanum was noted and recent work confirmed the species identification (Põldmaa 1997, Kurkela et al. 1999, Hantula et al. 2009). The disease causes considerable damage to alder foliage in late summer, when diseased trees can easily be seen from a distance. All the foliage turns brown and the leaf margins curl inward. Successive infections can cause tree death.

$M$. hiratsukanum was first described on Manchurian alder [Alnus hirsuta (Spach) Turcz. ex Rupr.] in Japan. It is a heteroecious rust that produces spermagonia and aecia on larch (Larix spp.) needles, and uredinia and telia on the leaves of alders. The occurrence of $M$. hiratsukanum on naturally infected foliage of both Dahurian larch $(L$. dahurica Turcz. \& Trautv.) and Siberian larch $(L$. sibirica Ledeb.) in Finland and of the identical ITS sequence of the fungus obtained from grey alder (A. incana) and Siberian larch within a mixed stand provide strong evidence that larch is involved in the natural life cycle of $M$. hiratsukanum in Finland (Hantula et al. 2009).

Outbreaks of foliar rust on alders have recently been reported from many other European countries too. The rust has been identified as $M$. hiratsukanum based on its morphology (Gjaerum et al. 2004, Sert and Sumbul 2005).

To investigate the possibility that the recent European rust epidemic is of an east Asian ori- 
Vol. 20(2011): 74-85.

gin, Hantula et al. (2009) showed that the Finnish pathogen utilized Asian larch species as alternate hosts. In inoculation trials, M. hiratsukanum, found on naturally-infected alder, could infect larch species from Eurasia, (Dahurian and Siberian larches), Europe [European larch (L. decidua Miller)] and North America [Alaskan larch, (L. laricina (Du Roi) C. Koch)] (Hantula et al. 2009). The pathogen was also present in naturally infected foliage of both Dahurian and Siberian larches in Finland (Hantula et al. 2009). The natural distribution of larch trees provides an unbroken range of alternate hosts capable of supporting $M$. hiratsukanum extending from the Pacific coast of the Russian Federation in the east through Siberia to the White Sea in the west (Krüssmann 1960). Similarly, the natural range of Manchurian alder stretches from Japan in the east through western Siberia where its distribution overlaps that of Eurasian grey alder. The latter species extends westwards as far as the Atlantic coasts of Scandinavia and southwestern Europe (Jalas and Suominen 1976, EPPO 2000). There was, however, a natural gap in the distribution of Dahurian/Siberian and European larches in Eastern Europe, including Finland, which was closed by foresters during the last few centuries. Therefore, a natural migration of $M$. hiratsukanum from the Far East to Europe could have occurred given the continuity of both main and alternate hosts for the pathogen within the intervening area. This route of entry into Europe would be consistent with the broad front over which new records of $M$. hiratsukanum have been reported since the mid-1990s. This front extends from Finland and Norway in the north to Turkey in the south (Kurkela et al. 1999, Gjaerum et al 2004, Sert and Sumbul 2005).

A comparison of $M$. hiratsukanum urediniospore morphology found no differences among samples from Austria, Estonia, Finland, Japan, or Switzerland (Hantula et al. 2009). Furthermore, sequence analysis of the ITS region for a selection of these samples detected only minor differences and revealed that $M$. hiratsukanum in East Asia and Europe belong to a single palearctic population (Hantula et al. 2009). Thus, as proposed earlier by Kurkela and Hantula (1999), it seems likely that the natural spread of a new rust species through
Siberia from East Asia caused the recent European epidemic of foliar rust on alders.

\section{Dothistroma septosporum, an epidemic possibly associated with climate change}

Red band needle blight, caused by Dothistroma septosporum (Dorog.) and D. pini (Hulbary), is an economically important disease causing premature defoliation. The perfect stage of $D$. septosporum is Mycospaerella pini Rostr. (Barnes et al. 2004), whereas that of $D$. pini is unknown (Barnes et al. 2008). Red band needle blight is caused in Europe mainly by $D$. septosporum while $D$. pini has so far been reported here only occasionally (Barnes et al. 2007). Many coniferous hosts are susceptible, but over 69 species of 2-, 3- and 5-needle pines (Pinus spp.) are particularly vulnerable to the disease worldwide (Ivory 1994, Gibson 1979, Barnes et al. 2008). Scots pine has generally a low susceptibility to Dothistroma and the most serious epidemics occur on pines when cultivated outside their natural distribution area (Watt et al. 2009).

The typical symptoms of red band needle blight were found on Scots pine during the summers of 2007 and 2008 in 14 rural districts of southern and central Finland (Müller et al. 2009). Red bands with aggregations of conidial stromata on otherwise brown, attached needles were frequently observed on saplings and young trees in dense stands and occasionally on the lower twigs of mature trees (Müller et al. 2009). Disease symptoms were also observed on the needles of both lodgepole pine ( $\mathrm{Pi}$ nus contorta Douglas ex Loudon) and cembra pine (P. cembra L.), which sometimes occur in Finland as introduced species (Müller et al. 2009). Subsequent infections have been found on European black pine ( $P$. nigra Arnold) and mountain pine ( $P$. mugo Turra) ornamentals.

Pure cultures of D. septosporum were obtained from acervuli on the needles of pine trees in various forest sites and their identification was verified by sequencing (Müller et al. 2009). Sequences of the ITS-region (including 5.8S rRNA gene) obtained from Finnish isolates were identical to each other 


\section{Lilja, A. et al. Introduced pathogens found on ornamentals, strawberry and trees}

and over 50 published sequences of D. septosporum (Müller et al. 2009). In a nursery experiment, brown segments and red bands appeared on inoculated 1-year-old seedlings of Scots pine within a month and conidial stromata could be seen on needles 2 to 4 weeks after the first symptoms (Müller et al. 2009).

Symptoms and conidial stromata were found on needles of forest trees after a mild and rainy winter (Müller et al. 2009). Thus, prevalence of the disease might be associated with winter conditions more typical of more southern latitudes or those predicted under models of global climate change (Woods et al. 2005). In 2006, D. septosporum was found on pines in Estonia (Hanso and Drenkhan 2008) and perhaps the spores reached Finnish pine forests via aerial dispersal from Estonia across the Gulf of Finland, a distance of 50 to $100 \mathrm{~km}$. Results from the inoculation experiment and probable aerial dissemination suggest that this introduced species possibly occurs in Finnish nurseries although the low number of pines produced and routine application of fungicides restrict its detection and limit its establishment.

\section{Chalara fraxinea, a destructive pathogen of common ash}

During the last few decades common ash (Fraxinus excelsior L.) in Europe has shown extensive decline and mortality. A recently described fungus, Chalara fraxinea $\mathrm{T}$. Kowalski, is responsible for the disease (Kowalski 2006, Kowalski and Holdenrieder 2009a, Bakys et al. 2009a,b). Kowalski and Holdenrieder (2009b) have suggested that the teleomorph of C. fraxinea is Hymenoscyphus albidus (Rodge ex Desm.) W. Phillips, an ascomycete known in Europe for a long time and considered a harmless decomposer of fallen leaves (Ellis and Ellis 1997). However, some recent studies showed certain genetic differences among Hymenoscyphus isolates in areas devastated by the disease, as compared to areas where the disease has not yet been observed and a new species, H. pseudoalbidus V. Queloz, C.R. Günig, R. Berndt, T., Kowalski, T.N. Sieber
\& O. Holdenrieder responsible for ash decline has been described (Queloz et al. 2011).

Symptoms were first observed in Lithuania and Poland during the 1990s (Juodvalkis and Vasiliauskas 2002, Przybył 2002). By 2002, approximately $60 \%$ of the ash stands in Lithuania had been killed by ash dieback (Vasaitis and Lygis 2008). Today, $80 \%$ of ash stands in Poland are affected and ash decline has been observed to spread into many other countries including e.g., Finland, Estonia and Latvia (Rytkönen et al. 2011).

Symptoms of the disease include wilting caused by necrotic lesions and stem and branch cankers. Necrosis is also present on leaves, petioles and achenes. Usually, top dieback is the first symptom to be noticed. Trees are dying in all age classes in forest stands as well as in parks and nurseries (Kowalski 2006, Bakys et al. 2009a,b). While C. fraxinea occurs abundantly on diseased trees, declining ashes are also colonized by other potentially pathogenic fungi in the genera Alternaria, Cytospora, Diplodia, Fusarium, Phoma, Phomopsis and Armillaria (Przybył 2002, Lygis et al. 2005, Bakys et al. 2009a,b).

Kowalski and Holdenrieder (2009a) showed using field inoculations that $C$. fraxinea caused stem lesions similar to those in nature. In Sweden, molecular techniques were used to detect the pathogen in common ash and it was found that isolates could cause bark and cambium necrosis in artificial inoculations (Bakys et al. 2009a,b). Kirisits et al. (2009) found $C$. fraxinea in narrow-leaved ash (F. angustifolia Vahl.) and that it was also pathogenic to this host in inoculation trials. Recent investigations of secondary metabolite production of C. fraxinea led to the isolation of the phytotoxin viridiol and the fungistatic compound viridin (Andersson et al. 2010).

C. fraxinea has often been detected with DNA-methodology in symptomless petioles, although isolations have failed from tissue adjacent to a necrotic area (Bakys et al. 2009). This fungus grows slowly in culture and can easily be overgrown by other species during isolation. The identification is also time-consuming since the production of phialides on agar takes several weeks (Kowalski 2006). To overcome these problems at 
Vol. 20(2011): 74-85.

least two species specific ITS-primer pairs have recently been developed for its molecular detection (Chandelier et al. 2010, Johansson et al. 2010).

In Finland, the first signs of ash decline were seen first in the Alland archipelago in 2000 and later in 2007 in mainland. Although ash is indigenous only in southern Finland, the ash can be grown in the central part of the country where it is used widely as an amenity tree. To date, $C$. fraxinea has only been isolated from trees in southwest Finland and the Åland archipelago (Rytkönen et al. 2011).

The spores of Hymenoschyphus are likely more important for dispersal of the disease than are the sticky conidia of $C$. fraxinea (Kowalski and Holdenrieder 2009). Although insect vectors are important in the dispersal of several species of Chalara (Nag Raj and Kendrick 1993), none have been shown to carry $C$. fraxinea.

\section{Conclusions}

Globalization has led to a rapid increase in the trade of plants, most of which are used as ornamentals. The trade has also increased the spread of associated organisms, some of which are plant pathogens (Hansen 2008, Desprez-Loustau et al. 2010). Simultaneously, climate change predictions are going to affect the distribution and virulence of pathogens, many of which have not been considered important because of an unfavorable climate (Desprez-Loustau et al. 2007). It is interesting that although the ornamental plant trade has obviously been the most frequently utilized pathway for pathogens to reach Finland, organisms arriving by more natural means have so far caused the most extensive damage. Furhermore, many of these new pathogens appear on ornamentals or amenity trees, the socioeconomic value of which often exceeds that of forest trees.

Ornamental plants host many Phytophthora species, pathogens that are supposed to have originated from more temperate regions than Finland. To date, four Phytophthora species have been identified in Finland: P. cactorum on Fragaria $\mathrm{x}$ ananassa, Betula pendula and Rhododendron spp.,
P. plurivora on Rhododendron spp. and Syringa vulgaris, and P. pini and P. ramorum on Rhododendron spp. (Lilja et al. 1996, 2010). None of them are host specific, but may cause different symptoms depending on the host plant (Erwin and Ribeiro 1996, Werres et al. 2001, Rizzo et al. 2005, Jung and Burgess 2009, Thinggaard 2009). We have only isolated these Phytophthora species from nursery seedlings or strawberry plants, but $P$. cactorum and $P$. plurivora are known to cause necrotic lesions, root rot and high mortality also in trees growing naturally in Germany and Denmark (Werres et al. 1995, Thinggaard 2009). Phytophthora ramorum has been detected on trees in Great Britain and the Netherlands and on ornamentals in most European countries (Brasier et al. 2004, EPPO 2010).

Climate change will also increase many foliar diseases such as rusts, powdery mildews and many other fungi will benefit from increased precipitation (Woods et al. 2005, Desprez-Loustau et al. 2007). Woods et al. (2005) found that a relatively small increase in rainfall was the primary cause of the Dothistroma septosporum epidemic in northwest British Columbia (Woods et al. 2005). In Finland, typical symptoms of red band needle blight were first documented in 2007 (Müller et al. 2009), and alder rust Melampsoridium hiratsukanum has caused early shedding of alder leaves since 1995 (Hantula et al. 2009). Both of these introduced pathogens will likely benefit from increasing precipitation during the summer months.

The recently described and emerging ash decline disease, caused by Chalara fraxinea, might in the future be a serious threat to ashes in Europe. The first signs of the disease in Finland were seen in the Åland archipelago and later in the southwest mainland (Rytkönen et al. 2011). As no diseased trees have yet been found in eastern Finland, it seems that the epidemic is spreading eastwards through the contiguous distribution of ash species in Southern Finland (Rytkönen et al. 2011). If the disease is as aggressive in Finland as it has been in other Baltic countries, there is an urgent need for a selective breeding program to develop strains of $F$. excelsior resistant to the pathogen.

Since 2004, when P. ramorum was first detected in a Finnish ornamental nursery, the Finn- 


\section{Lilja, A. et al. Introduced pathogens found on ornamentals, strawberry and trees}

ish Food Safety Authority (Evira) has carried out extensive on-site surveys. Today, the pathogen can still be detected there although all rhododendron seedlings and growth media have been destroyed every year in the area where the disease has been found (Lilja et al. 2010). Similarly, the presence of a second alien pathogen, Colletotrichum acutatum, was confirmed by PCR from bait plants grown in soil collected from the field where infected plants had earlier been destroyed (Lilja et al. 2006).

Climate change is expected to increase the mean temperature in Finland by $1-3{ }^{\circ} \mathrm{C}$ and climatic extremes such as drought, heavy rains and storms to become more frequent (Jylhä et al. 2009). Under such conditions, plants will be subjected to intense periods of stress more often (Woods et al. 2005, Deprez-Loustau et al. 2007). Studies over the past 20 years have shown that new pathogens are arriving in Finland with increasing frequency. While the influence of future climate change on the prevalence, spread and severity of diseases caused by new pathogens is difficult to predict, in several cases the native Finnish flora has already suffered greatly or is currently facing serious threats from emerging diseases.

Acknowledgements. The authors would like to thank Dr. Michael Hardman for his comments on the manuscript. His proposals and changes are gratefully observed. He also revised the English.

\section{References}

Andersson, P.F., Johansson, S.B.K., Stenlid, J. \& Broberg, A. 2010. Isolation, identification and necrotic activity of viridiol from Chalara fraxinea, the fungus responsible for dieback of ash. Forest Pathology 40: 43-46.

Bakys, R., Vasaitis, R., Barklund. P., Ihrmark, K. \& Stenlid, J. 2009a. Investigations concerning the role of Chalara fraxinea in declining Fraxinus excelsior. Plant Pathology 58: 284-292.

Bakys, R., Vasaitis, R., Barklund, P., Thomsen, I.M. \& Stenlid, J. 2009b. Occurrence and pathogenicity of fungi in necrotic and non-symptomatic shoots of declining common ash (Fraxinus excelsior) in Sweden. European Journal of Forest Pathology 128: 51-60.

Barnes, I., Crous, P.W., Wingfield, M.J. \& Wingfield, B.D. 2004. Multigene phylogenesis reveals that red band needle blight of Pinus is caused by two distinct species of Dothistroma: D. septosporum and D. pini. Studies in Mycology 50: 551-565.

Barnes, I., Kirisits, T., Akulov, A., Chhetri, D.B., Wingfield, M.J., Bulgakov, T. \& Wingfield, B. 2007. New reports of Dothistroma needle blight in Eurasian countries. In Szabo, I. (ed.), Acta Silvatica \& Lignaria Hungarica. Special Edition: Proceedings of the Conference of IUFRO Working Party 7.02.02, 21-26 May 2007 Sopron, Hungary, p.237-238.

Barnes, I., Kirisits, T., Akulov, A., Chhetri, D.B., Wingfield, B.D., Bulgakov, T.S. \& Wingfield, M.J. 2008. New hosts and country records of the Dothistroma needle blight pathogens from Europe and Asia. Forest Pathology 38: 178-195.

Berrie, A.M. \& Burgess, C.M. 2003. A review of research on epidemiology and control of blackspot of strawberry (Colletotrichum acutatum) with special reference to weeds as alternative hosts. In: Gordon, S.C. \& Cross, J.V. (eds.), Proceedings of the IOBCWPRS Working Group, International Plant Protection In Orchards. Subgroup Soft fruits, Dundee, Scotland 18-21. September 2001. Bulletin-OILS-STROP 26: 163-168.

Brasier, C.M. 2003. Sudden oak death exhibits transatlantic differences. Mycological Research 107: 258-259.

Brasier, C.M., Denman, S., Brown, A. \& Webber, J. 2004. Sudden oak death (Phytophthora ramorum) discovered on trees in Europe. Mycological Research 108: 1108-1110.

Cave, G.L., Randall-Schadel, B \& Redlin, S.R. 2005. Risk analysis for Phytophthora ramorum Werres de Cock \& In't Veld causal agent of Phytophthora canker (Sudden Oak Death) Ramorum leaf blight and Ramorum dieback. USDA. Animal and Plant Health Inspection Service. Plant Protection and Quarantine2005. Rev.1. 77 p.

Chandelier, A., André, F. \& Laurent, F. 2010. Detection of Chalara fraxinea in common ash (Fraxinus excelsior) using real time PCR. Forest Pathology 40: 87-95.

Davidson, J.M., Wickland, A.C., Patterson, H.A., Falk, K.R. \& Rizzo, D.M. 2005. Transmission of Phytophthora ramorum in mixed-evergreen forest in California. Phytopathology 95: 587-596.

Denman, S., Kirk, S.A., Brasier, C.M. \& Webber, J.F. 2005. In vitro leaf inoculation studies as an indication of tree foliage susceptibility to Phytophthora ramorum in the UK. Plant Pathology 54: 512-521.

Desprez-Loustau, M.-L., Courtecuisse, R., Robin, C. Husson, C., Moreau, P.-A., Blancard, D., Selosse, M.-A., Lund-Escarmant, B., Piou, D. \& Sache, I. 2010. Species diversity and drivers of spread of alien fungi (sensu lato) in Europe with a particular focus on France. Biological Invasions 12: 157-172.

Desprez-Loustau, M.-L., Robin, C., Reynaud, G., Déqué, M., Badeau, V., Piou, D., Husson, C. \& Marcais, B. 2007. Simulating the effect of a climate-change scenario on the geographical range and activity of forest pathogenic fungi. Canadian Journal of Plant Pathology 29: 101-120.

Eastburn, D.M. \& Gubler, W.D. 1990. Strawberry anthracnose; detection and survival of Colletotrichum acutatum in soil. Plant Disease 74: 161-163.

Eastburn, D.M. \& Gubler, W.D. 1992. Effects of soil moisture and temperature on the survival of Colletotrichum acutatum. Plant Disease 76: 841-842. 
Vol. 20(2011): 74-85.

Eikemo, H., Klemsdal, S.S., Riisberg, I., Bonats, P., Stensvad, A \& Tronsmo, A.M. 2004. Genetic variation between Phytophthora cactorum isolates differing in their ability to cause crown rot in strawberry. Mycological Research 108: 317-324.

Ellis, M.B \& Ellis, J.P. 1997. Microfungi on land plants. New enlarged edition. The Richmond Publishing Co. Ltd. p.137.

EPPO, European and Mediterranean Plant Protection Organization, 1997. Data sheets on quarantine pests. Co/letotrichum acutatum. Cited 17 Janyary 2011. Available on the Internet: http://www.eppo.org/QUARANTINE/fungi/Colletotrichum acutatum/COLLAC ds.pdf

EPPO, 2000. Distribution of the main forest trees and shrubs on the territory of the former USSR. European Plant Protection Organisation Document 00/7806.

EPPO, 2010. Data sheets on quarantine pests Phytophthora ramorum. Cited 17 Janyary 2011. Updated 02 Febryary 2010. Available on the Internet: http://www. eppo.org/QUARANTINE/Alert_List/fungi/PHYTRA.htm

Erwin, D.C. \& Ribeiro, O.K. 1996. Phytophthora Diseases Worldwide. APS Press St. Paul Minnesota. 562 p.

Freeman, S., Horowitz, S. \& Sharon, A. 2001. Pathogenic and nonpathogenic lifestyles in Colletotrichum acutatum from strawberry and other plants. Phytopathology 91: 986-992.

Gäumann, E. 1959. Die Rostpilze Mitteleuropas. Beitr Cryptogamenfl Schweiz 12. Buchdruckerei Büchler Bern. 1407 p. (In German).

Gibson, I.A.S. 1979. Diseases of forest trees widely planted as exotics in the tropics and southern hemisphere. Part II. The genus Pinus. Commonwealth Mycological Institute/Commonwealth Forestry Institute Kew UK. 135 p.

Gjaerum, H.B., Lye, K.A \& Solheim, H. 2004. First record of Melampsoridium hiratsukanum on alder in Norway. Plant Pathology 53: 530.

Goss, E.M., Carbone, I. \& Grünwald, N.J. 2009. Ancient isolation and independent evolution of the three clonal lineages of the exotic sudden oak death pathogen Phytophthora ramorum. Molecular Ecology 18: 1161-1174.

Grove, G.G., Ellis, M.A., Madden, L.V. \& Schmitthenner, A.F. 1985. Overwinter survival of Phytophthora cactorum in infected strawberry fruit. Plant Disease 69: 514-515.

Hansen, E.M. 2008. Alien forest pathogens: Phytophthora species are changing world forests. Boreal Environmental Research 13: 33-41.

Hansen, E.M., Goheen, D.J., Jules, E.S. \& Ullian, B. 2000. Managing Port Orford Cedar and introduced pathogen Phytophthora lateralis. Plant Disease 84: 4-14.

Hansen, E.M., Parke, J.L. \& Sutton, W. 2005. Susceptibility of Oregon forest trees and shrubs to Phytophthora ramorum: a comparison of artificial inoculation and natural infection. Plant Disease 89: 63-70.

Hanso, M. \& Drenkhan, R. 2008. First observations of Mycospaerella pini in Estonia. Plant Pathology 57: 1177.

Hantula, J., Lilja, A. \& Parikka, P. 1997. Genetic variation and host specificity of Phytophthora cactorum isolated from Europe. Mycological Research 101: 565-572.

Hantula, J., Lilja, A., Nuorteva, H., Parikka, P. \& Werres, S. 2000. Pathogenicity, morphology and genetic variation of Phtytophthora cactorum from strawberry, apple, rhododendron and silver birch. Mycological Research 104: 1062-1068.
Hantula, J., Kurkela, T., Hendry, S. \& Yamaguchi, T. 2009. Morphological measurements and ITS-sequences show that the new alder rust in Europe is conspecific to Melampsoridium hiratsukanum in East Asia. Mycologia 101: 622-631.

Hong, C.X. 2009. Phytophthora disease mitigation through pump and inlet placement in recycling irrigation systems. Cited 17 January 2011. Available on the Internet: http:// www.reeis.usda.gov.web/crisprojectpages/204053.html

Huang, H., Jeffers, S.N., Layne, D.R. \& Snabel, G. 2004. AFLP analysis of Phytophthora cactorum isolates from strawberry and other hosts: Implications for identifying the primary source of inoculum. Plant Disease 88: 714-720.

Ivory, M.H. 1994. Records of foliage pathogens of Pinus species in tropical countries. Plant Pathology 43: 511518.

Jalas, J. \& Suominen, J. 1976. Atlas Florae Europaeae - Distribution of Vascular Plants in Europe. Volume 3. Salicaceae to Balanophoraceae. Committee for Mapping the Flora of Europe \& Societas Biologica Fennica Vanamo Helsinki.

Johansson, S.B.K., Vasaitis, R., Ihrmark, K., Barklund, P. \& Stenlid, J. 2010. Detection of Chalara fraxinea from tissue of Fraxinus excelsior using species-specific ITS primers. Forest Pathology doi: 10.1111/j.14390329.2009.00614.x.

Jung, T. \& Blaschke, H. 1996. Phytophthora root rot in declining forest trees. Phyton 36: 95-102.

Jung, T. \& Burgess, T.I. 2009. Re-evaluation of Phytophthora citricola isolates from multiple woody hosts in Europe and North America reveals a new species, Phytophthora plurivora sp. nov. Persoonia 22: 95-110.

Jung, T., Hudler, G.W., Jensen-Tracy, S.L., Griffiths, H.M., Fleischmann, F. \& Oßwald, W.B. 2005. Involvement of Phytophthora spp. in the decline of European beech in Europe and the USA. Mycologist 19: 159-166.

Jung, T. \& Nechwatal, J. 2008. Phytophthora gallica sp. nov., a new species from rhizosphere soil of declining oak and reed stands in France and Germany. Mycological Research 112: 1195-1205.

Juntunen, M.-L. 2000. Weeds, diseases, insects and mites and use of pesticides in Finnish forest nurseries - results of a survey study. Finnish Forest Research Institute, Research Papers 781: 17-32.

Juodvalkis, A. \& Vasiliauskas, A. 2002. The extent and possible causes of dieback of ash stands in Lithuania. LŽŪU Moksolo Darbai Biomedicinos Mokslai 56: 17-22.

Jylhä, K., Ruosteenoja, K., Räisänen, J., Venäläinen, A., Tuomenvirta, H., Ruokolainen, L., Saku, S. \& Seitola, T. 2009. The changing climate in Finland: estimates for adaptation studies. ACCLIM project report 2009. Finnish Meteorological Institute. Reports 2009:4.

Kirisits, T., Matlakova, M., Mottinger-Kroupa, S., Halmschlager, E. \& Lakatos, F. 2009. Chalara fraxinea associated with dieback of narrow-leafed ash (Fraxinus angustifolia). New Disease Reports. Volume 19, 43. Available in the Internet: http://www.bspp.org.uk/publications/ new-disease-reports/volumes.php

Kong, P., Hong, C., Richardson, P.A. \& Gallegly, M.E. 2003. Single-strand-conformation polymorphism of ribosomal DNA for rapid species differentiation in genus Phytophthora. Fungal Genetics and Biology 39: 238-249. 


\section{Lilja, A. et al. Introduced pathogens found on ornamentals, strawberry and trees}

Kowalski, T. 2006. Chalara fraxinea sp. nov. associated with dieback of ash (Fraxinus excelsior) in Poland. Forest Pathology 36: 264-270.

Kowalski, T. \& Holdenrieder, O. 2009a. Pathogenicity of Chalara fraxinea. Forest Pathology 39: 1-7.

Kowalski, T. \& Holdenrieder O. 2009b. The teleomorph of Chalara fraxinea the causal agent of ash dieback. Forest Pathology 39: 304-308.

Krüssmann, G. 1960. Die Nadelgehölze. Paul Parey, Berlin. (In German).

Kurkela, T., Hanso, M. \& Hantula, J. 1999. Differentiating characteristics between Melampsoridium rusts infecting birch and alder leaves. Mycologia 91: 987-992.

Kurkela, T. \& Hantula, J. 1999. Uusi metsäpuun tauti leviää Suomessa. Metsälehti 19:10/7. (In Finnish).

Leandro, L., Gleason, M.L., Nutter, F.W. Jr., Wegulo, S. \& Dixon, P. 2001.Germination and sporulation of Colletotrichum acutatum on symptomless strawberry leaves. Phytopathology 91:659-664.

Lilja, A., Rikala, R., Hietala, A. \& Heinonen, R. 1996. Fungi isolated from necrotic stem lesions of Betula pendula seedlings in forest nurseries and the pathogenicity of Phytophthora cactorum. European Journal of Forest Pathology 26: 89-96.

Lilja, A., Karjalainen, R., Parikka, P., Kammiovirta, K. \& Nuorteva, H. 1998. Pathogenicity and genetic variation of Phytophthora cactorum from silver birch and strawberry. European Journal of Plant Pathology 104: 529-535.

Lilja, A., Parikka, P., Pääskynkivi, E., Hantula, J., Vainio, E., Vartiamäki, H., Lemmetty, A. \& Vestberg, M. 2006. Phytophthora cactorum and Colletotrichum acutatum: Survival and detection. Agriculturae Conspectus Scietificus 71: 121-128.

Lilja, A., Rytkönen, A., Kokkola, M., Parikka, P. \& Hantula, J. 2007. First report of Phytophthora ramorum and $P$. inflata in ornamental rhododendrons in Finland. Plant Disease 91: 1055.

Lilja, A., Rytkönen, A., Hantula, J., Müller, M. \& Kurkela, T. 2010. Phytophthora cactorum, P. ramorum, P. plurivora, Melampsoridium hiratsukamum, Dothiostroma septosporum and Chalara fraxinea, non-native pathogens in Finland. In: Cram, M. (ed.) Proceedings of the $7^{\text {th }}$ Meeting of IUFRO Working Party 7.03.04. Diseases and Insects in Forest Nurseries. Forest Health Protection Report 10-01-01: 55-62.

Lygis, V., Vasiliauskas, R., Larsson, K.-H. \& Stenlid, J. 2005. Wood-inhabiting fungi in stems of Fraxinus excelsior in declining ash stands of northern Lithuania with particular reference to Armillaria cepistipes. Scandinavian Journal of Forest Research 20: 337-346.

Madden, L.V., Wilson, L.L., Yang, X. \& Ellis, M.A. 1992. Splash dispersal of Colletotrichum acutatum and Phytophthora cactorum by short-duration simulated rains. Plant Pathology 41: 427-436.

Müller, M.M., Hantula, J. \& Vuorinen, M. 2009. First observations of Mycosphaerella pini on Scots Pine in Finland. Plant Disease 93: 322.

Nag Raj, T.R. \& Kendrick, W. 1993. The anamorph as generic determinant in the holomorph: the Chalara connection in the Ascomycetes with special reference to the ophiostomatoid fungi. In: Wingfield, M.J., Seifert, K.A. \& Webber, J.F. (eds.). Ceratocystis and Ophiostoma: taxonomy, ecology and pathogenicity. The American Phy- topathological Society, St. Paul Minnesota. p. 61-70.

Nechwatal, J. \& Oßwald, W. 2001. Comparative studies on the fine root status of healthy and declining spruce and beech trees in the Bavarian Alps and occurrence of Phytophthora and Pythium species. Forest Pathology 31: 257-273.

Norman, D.J. \& Strandberg, J.O. 1997. Survival of Colletotrichum acutatum in soil and plant debris of leatherleaf fern. Plant Disease 81: 1177-1180.

Oudemans, P., Föster, H. \& Coffey, M.D. 1994. Evedence for distinct isozyme subgroups witin Phytophthora citricola and close relationships with $P$. capsici and $P$. citrophora. Mycological Research 98: 189-199.

Parikka, P. 1990. Nahkamätä vaivaa mansikkaa. Puutarha 9/90: 630-631. (In Finnish).

Parikka, P. \& Kokkola, M. 2001. First report of Colletotrichum acutatum on strawberry in Finland. Plant Disease 85: 923.

Parikka, P. \& Lemmetty, A. 2004. Tracing latent infection of Colletotrichum acutatum on strawberry by PCR. European Journal of Plant Pathology 110: 393-398.

Parikka, P. \& Lemmetty, A. 2009. Colletotrichum acutatum: Survival in Plant Debris and Infection of some weeds and Cultivated Plants. Acta Horticulturae 842: 307-310.

Parikka, P., Pääskynkivi, E. \& Lemmetty, A. 2006. Survival of Colletotrichum acutatum in dead plant material and soil in Finland. Acta Horticulture 708: 131-134.

Põldmaa, K. 1997. Explosion of Melampsoridium sp. on Alnus incana. Folia Cryptogamica Estonica 31: 48-51.

Prospero, S., Grünwald, N.J., Winton, L.M. \& Hansen, E.M. 2009. Migrigation patterns of the emerging plant pathogen Phytophthora ramorum on the West Coast of United States of America. Phytopathology 99: 739-749.

Przybył, K. 2002. Fungi associated with necrotic apical parts of Fraxinus excelsior shoots. Forest Pathology 32: 387-394.

Queloz, V., Grünig, R., Berndt, T., Kowalski, T., Sieber, T.N. \& Holdenrieder, O. 2011. Cryptic spesification of Hymenoscyphus albidus. Forest Pathology DOI:10.1111/j.14390329.2010.00645.x.

Rizzo, D.M., Garbelotto, M., Davidson, J.M. \& Slaugter, G.W. 2002. Phytophthora ramorum as the cause of extensive mortality of Quercus spp. and Lithocarpus densiflorus in California. Plant Disease 86: 205-214.

Rizzo, D.M., Garbelotto, M. \& Hansen, E.M. 2005. Phytophthora ramorum: integrative research and management of an emerging pathogen in California and Oregon forests. Annual Review of Phytopathology 43: 309-335.

Roll-Hansen, F. \& Roll-Hansen, H. 1981. Melampsoridium on Alnus in Europe; M. alni conspecific with M. betulinum. European Journal of Forest Pathology 11: 77-87.

Rytkönen, A., Lilja, A., Hantula, J., Drenkhan, R. \& Gaitniels, T. 2011. First record of Chalara fraxinea in Finland and genetic variation among isolates sampled from Åland, mainland Finland and Estonia. Forest Pathology DOI: 10.1111/j.1439-0329.2010.00647.x.

Sakai, A.K, Allendorf, F.W., Holt, J. S., Lodge, D. M., Molofsky, J., Baughman, S., Cabin, R.J., Cohen, J.E., Ellstrand, N.C., McCauley, D.E., O'Neil, P., Parker, I. M., Thompson, J.N. \& Weller, S.G. 2001. The population biology of invasive species. Annual Review of Ecological Systematics 32: 305-332.

Scott, P.M., Burgess, T.I., Barber, P.A., Shearer, B.L., 


\section{AGRICULTURAL AND FOOD SCIENCE}

Vol. 20(2011): 74-85.

Stukely, M.J.C., Hardy, G.E.St.J. \& Jung, T. 2009. Phytophthora multivora sp. nov. , a new species recovered from declining Eucalyptus, Banksia, Agonis and other plant species in Western Australia, Persoonia 22: 1-13.

Sert, H.B. \& Sumbul, H. 2005. First report of Melampsoridium hiratsukanum infecting alders (Alnus orientalis var. orientalis) in Turkey. Plant Pathology 54: 241.

Stamps, D.J., Waterhouse, G.M., Newhook, F.J. \& Hall, G.S. 1990. Revised tabular key to the species of Phytophthora. Commonwealth Mycology Institute Mycological Papers No 162, 28 p.

Stensvand, A., Talgø, V., Strømeng, G. M., Aamot, H.U., Børve, J., Sletten, A. \& Klemsdal, S. 2006. Colletotrichum acutatum in Norwegian strawberry production and sources of potential inoculum in and around strawberry fields. IOBC wprs Bulletin 29(9) 2006: 87-91.

Thinggaard, K. 2009. Phytophthora - en ny og alvorlig trussel mod de danske skove. Skoven 2009/11: 478481. (In Danish).

Vasaitis, R. \& Lygis, V. 2008. Emerging forest diseases in south-eastern Baltic Sea region. Network of Climate Change Risks on Forests (FoRisk): SNS Workshop Umea Sweden. p. 14-15.

Watt, M.S., Kiriticos, D.J., Alcaraz, S., Brown, A.V. \& Leriche, A. 2009. The hosts and potential geographic range of Dothistroma needle blight. Forest Ecology and Management 257: 1505-1519.
Werres, S. \& Kaminski, K. 2005. Characterisation of European and North American Phytophthora ramorum isolates due to their morphology and mating behavior in vitro with heterothallic Phytophthora species. Mycological Research 109: 860-871.

Werres, S., Richter, J. \& Veser, I. 1995. Unersuchungen von kranken und abgestrorbenen Roßkastanien (Aesculus hippocastanum L.) im öffentlichen Grün. Nachrichtenblatt des Deutschen Pflanzenschutzdienstes 47: 81-85. (In German).

Werres, S., Marwitz, R., Man In't Veld, W.A., De Cock, W.A.M., Bonants, P.J.M., De Weert, K., Ilieva, E. \& Baayen, R.P. 2001. Phytophthora ramorum sp. nov. a new pathogen on Rhododendron and Viburnum. Mycological Research 105: 115-1165.

Wilson, I.L., Madden, L.V. \& Ellis, M.A. 1992. Overwinter survival of Colletotrichum acutatum in infected fruit in Ohio. Plant Disease 76: 948-950.

Wilson, M. \& Henderson, D.M. 1966. British rust fungi. Cambridge University Press. Cambridge. 384 p.

Woods, A., Coates, K.D. \& Hamann, A. 2005. Is an unprecedented Dothistroma needle blight epidemic related to climate change? BioScience 55: 761-769.

Zobel, D.B., Roth, L.F. \& Hawk, G.M. 1985. Ecology, pathology, and management of Port Orford Cedar (Chaemaecyparis lawsoniana). U.S. Department of Agriculture and Forest Service, General Technical Report PNW- 184. 